\title{
Improving Students Learning Outcome Using Group Investigation Model Combined with Think Pair Share and Course Review Horay
}

\author{
Mohammad Dani Wahyudi, Galuh Tripuspitaningrum \\ Department of Early Childhood Teacher Education \\ Universitas Lambung Mangkurat \\ Banjarmasin, Indonesia \\ mdaniwahyudi@ulm.ac.id, galuhtripus@gmail.com
}

\begin{abstract}
This study aims to determine the activities of teachers, students, and student learning outcomes in learning Social Sciences. This study used a qualitative approach with the type of Classroom Action Research (CAR) conducted in 2 cycles. The research subjects were VB grade students of SDN Pemurus Luar 1 Banjarmasin, totaling 25 people. Data collection techniques used observation and tests. Data analysis used is descriptive analysis. This can be seen from the results of research that show that teacher activities are very good criteria. Student activity has increased to a very active category. The completeness of student learning outcome has increased from $48 \%$ to $96 \%$. Based on the results of this study, it can be concluded that there is an increase in teacher activity, student activity, and student learning outcome using a Group Investigation learning model combined with Think Pair Share and Course Review Horay.
\end{abstract}

Keywords- Learning Outcomes, Group Investigation, Think Pair and Share, and Course Review Horay.

\section{INTRODUCTION}

In the current era of globalization, education must be the first capital in human life. Education becomes an important thing that can build people into more character. Education itself has always evolved from time to time; education makes it a reference that in the current era of globalization. Education is very important since it is able to develop the aspects of life in the world. Education also plays an important role in preparing human resources for life in the future. The right effort to prepare the quality human resources and the only container that can be seen as a tool to build high-quality human resources is education. Through the existence of the educational process itself, someone will find it easier to obtain the provision of life and self-ideals for their social life.

In the learning process, the success or failure of achieving goals depends on how the learning process is experienced by students. Learning is a business process carried out by someone to obtain a new change, as a result of his/her own experience in interaction with his environment [1]. From the above review, on the RI Government Regulation No. 32 of 2013 concerning the National Education Standards, article 19, it is stated that the learning process in educational units is held in an interactive, inspirational, fun, challenging, motivating students to participate actively, and provide sufficient space for initiative, creativity, and independence according to talent, interests and physical and psychological development of students [2]

In an effort to improve the quality of education, elementary schools are the earliest schools in the conceptualization of all science and students should be able to become active and independent children in the learning process. Improving the quality of education in elementary and secondary education is carried out on all subjects contained in content standards. One of which is the subject of Social Sciences "Because social studies education in elementary schools is a field of study that studies humans in all aspects of life and their interactions in society" [3]. Therefore, social studies subjects are one of the important subjects in elementary school. Understanding of students is also very necessary because it can design conducive learning that will be implemented to be able to improve the desired learning outcomes process. Over time, one of the things that can be a strategy in the learning process is by using approaches and models in learning in class, because by using the learning model, the learning process itself will be more interesting so that students do not feel bored. It is a strategy to improve the success of the teaching and learning process.

Through learning models in the classroom, things that want to be achieved ideally are the development of the potential of students and increased learning outcomes so that the achievement of social studies learning objectives is achieved. In the KTSP curriculum, the objectives of social studies subjects are in elementary/MI/ SDLB so that students have the following intended abilities. They are (1) Knowing various concepts relating to people's lives and the environment, (2) Having the basic ability to think logically and critically, curiosity, problem solving, and skill in social life, (3) Having commitment and awareness of social and humanitarian values, and (4) Having the ability to communicate, cooperate, and be competent in a pluralistic society, at the local, national level, and globally [4].

In SDN Pemurus Luar 1 Banjarmasin Class VB on social studies subjects, on the preparation for Indonesian independence day celebration, the students are expected to reach several things. Those are explaining the effort to prepare 
for independence, identifying the role of several figures, being able to show respect for the services of leaders in preparing for independence, and $80 \%$ of students are able to reach the score of 70 as the minimum requirement score. The student learning is also expected to be able to help them think critically and be actively involved in the learning process so that the learning outcomes obtained by students become even better.

But in reality, based on an interview with VB teacher at SDN Pemurus Luar 1 Banjarmasin, it was obtained that the students were indeed difficult in understanding the preparation material for Indonesian Independence. Many factors are low learning outcomes of class VB students of Pemurus Luar 1 Banjarmasin Elementary School about Preparation for Indonesian Independence. This fact is a challenge that must be answered because learning achievement is one indicator that becomes a benchmark for the success of learning.

From the results of these observations, it is also known that the low student learning outcomes are because the students feel bored with the learning process. Social studies learning is mostly only found in books, and the material only contains words that are not easily memorized and remembered. Therefore, it causes students' lack of motivation to learn, interest in the learning process, and learning process still only uses teacher-centered lecture methods, this causes active interactions between students and teachers or students with other students are rare. The learning does not become fun, and it resulted in a lack of learning motivation and a lack of active students in solving problems. Therefore, after being given assignments or evaluation questions, there are still many students who get less satisfactory (low) scores.

Based on the problems described above, a solution to solve the problems at SDN Pemurus Luar 1 Banjarmasin Class VB is sought so that the learning process is more meaningful and enjoyable and the students can develop motivation, interest, and activity to learn and are expected to improve the quality of learning outcomes students in the learning process. One method used is to use an approach that involves more student activities during the learning process, provides opportunities to develop their thinking skills, and changes the learning process more pleasantly. Therefore, the researchers used a combination of learning in the Cooperative Learning approach, namely GI, TPS, and CRH.

GI learning is one of the learning models that supports student involvement in learning activities [5]. This model can train students to grow their ability to think independently. Active student involvement can be seen from the first stage to the final stage of learning. In this model of learning, social interaction is one of the important factors for the development of a new mental scheme. Learning gives freedom to students to think analytically, critically, creatively, reflectively, and productively. Learning activities involve a variety of activities that are oriented towards investigating activities towards different learning resources both inside and outside of school.

The TPS learning model also has the advantage of providing opportunities for students to show their participation in others. Capabilities that are generally needed in this strategy are information sharing, asking questions, summarizing other people's ideas, and paraphrasing [6].
Meanwhile, the CRH learning model makes students more enthusiastic in social studies because most of the social studies learning is reading. It sometimes makes students feel bored. So using this model can help students eliminate boredom in the learning process [7] and this model also helps motivate students to be more diligent and thorough in learning because this model can be used to answer some questions provided by the teacher. In addition, this model can also have an impact that the class becomes more lively and enjoyable because every student who can answer questions correctly is obliged to shout hooray [7].

From the background review described above, the researchers focus on improving students learning outcome using Group Investigation Model Combined with Think Pair Share and Course Review Horay. The aim to be achieved in this study is to find out the teacher's activities, student activities and learning outcomes in mastering the preparation material for Indonesian independence using a Group Investigation model combination with Think Pair and Share and Course Review Horay in class VB of SDN Pemurus Luar 1 Banjarmasin.

\section{RESEARCH METHOD}

The type of research used was Classroom Action Research (CAR). The research subjects were VB grade students of SDN Pemurus Luar 1 Banjarmasin, totaling 25 people. Teacher and student activities during the learning process were measured through an observation sheet. Meanwhile, the student learning outcomes were measured using tests.

The researchers in this study used a type of quantitative and qualitative data. The qualitative data was data about the activities of teachers and students in learning activities with the GI model combined with TPS and CRH. Meanwhile, the quantitative data was collected from the student work results at the end of each meeting to measure the results of student mastery of the material provided.

The observation data on the activity of teachers with qualifications in the score of 34-40 obtains the criterion of "Very Good", score 26-33 with the criterion of "Good", score 18-25 with the criterion of "Fairly Good", and score 10-17 with the criterion of "Poor". Then, the data of student observation scores of 30-36 with classical completeness $82 \%-100 \%$ gets the criterion of "Very Active", score 23-29 with classical completeness $63 \%-81 \%$ get the criterion of "Active", score 1622 with classical completeness $44 \%-62 \%$ get the criterion of "Fairly Active", and if they get a score of 9-15 with classical completeness of $25 \%-43 \%$ then get the criterion of "Less Active". The indicators of success in this Classroom Action Research are 1) teacher activities are in Very Good criterion, namely $\geq 34,2$ ) student activities reach $\geq 82 \%$, and 3) student learning outcomes reach individual completeness if they get $\geq$ 70 , and completeness classics reached $\geq 82 \%$.

\section{RESULTS AND DISCUSSION}

Based on the results of the data analysis in this study, a process was carried out by applying the Group Investigation learning model with Think Pair and Share and Course Review 
Horay to VB graders in SDN Pemurus Luar 1 Banjarmasin cycle 1 to cycle 2 in teacher activities as follows in Tabel 1.

Table 1 shows the activities of teachers in conducting learning activities; it can be seen that at each meeting there is always an increase. The observation of teacher activity shows an increase in teacher activity at each meeting of cycle 1 which gets the criterion of "good" to get the criterion of "very good" in cycle 2 using a combination of GI models with TPS and $\mathrm{CRH}$ on learning and learning activities.

For more details based on the data that has been presented, the learning activities by applying the Group Investigation learning model in combination with Think Pair and Share and Course Review Horay carried out in 2 cycles have been carried out effectively and well and have increased the quality of learning. The trend of the increase can be seen in Figure 1.

\section{TABLE I. RECAPITULATION OF TEACHER ACTIVITIES}

\begin{tabular}{|c|c|c|}
\hline Cycle & Score & Criteria \\
\hline 1 & 31 & Good \\
\hline 2 & 36 & Very good \\
\hline
\end{tabular}

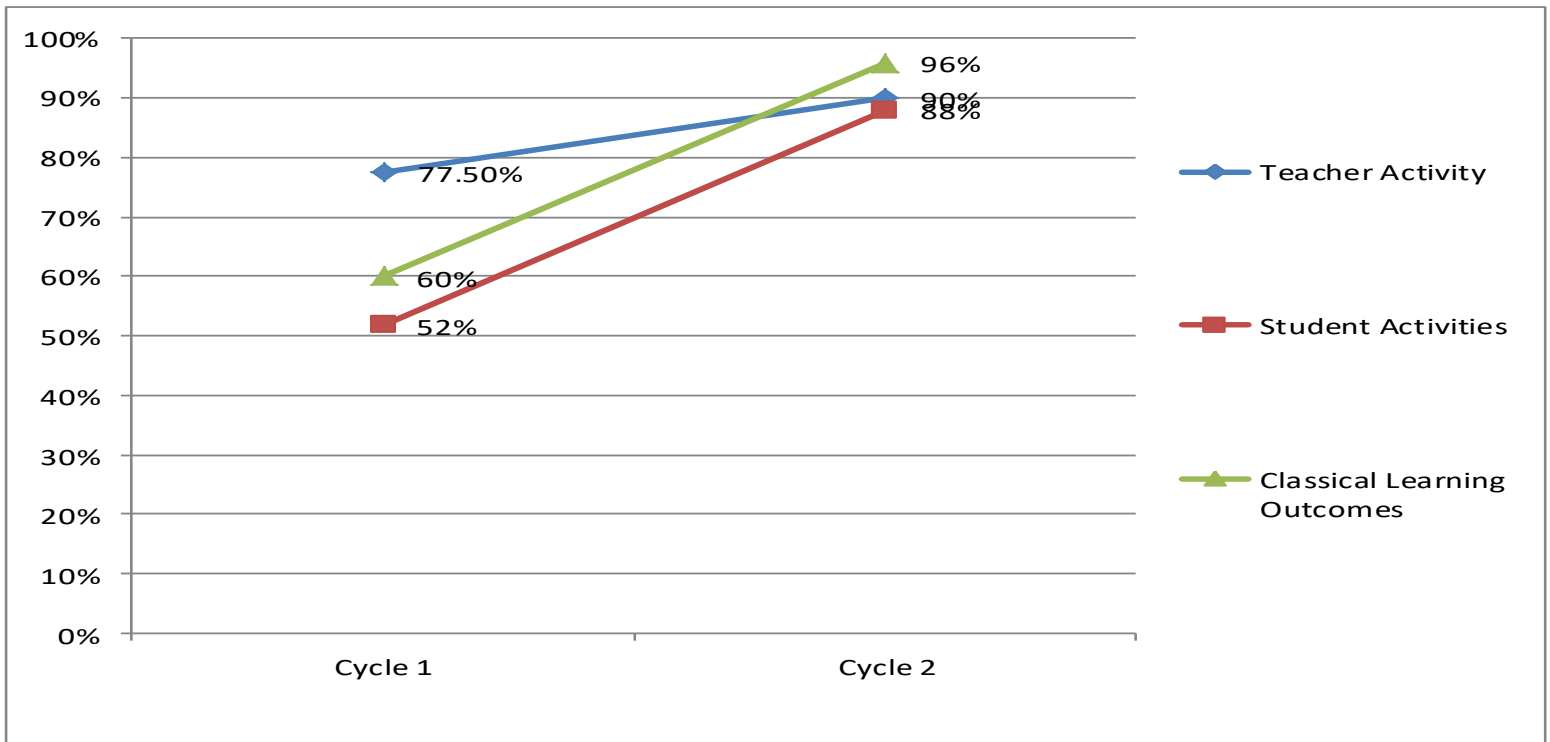

Fig. 1. Trend of Increasing Teacher Activity, Student Activities and Student Learning Outcomes

Based on Figure 1, it can be seen if the quality of teacher activities in cycle 1 gets a score of $70 \%$ increasing to $90 \%$ in cycle 2 , the activity of students in cycle 1 in a classical manner is $36 \%$ increasing to $88 \%$ in cycle 2 and student learning outcomes in a classical cycle 1 of $48 \%$ increased to $96 \%$ in cycle 2 . This result shows if all aspects studied are always increasing in each meeting.

Based on the result of this study, the teacher activity has increased from cycles 1 to 2 . The teacher was able to reflect on the results of activities that had been carried out in each cycle. One of the things that affects the increase in teacher activity is the teaching strategy carried out by the teacher. The successful implementation of a learning strategy will depend on the expertise of the teacher in using teaching methods, techniques, and tactics. One teacher teaching technique is to use a learning model in the teaching and learning process in the classroom. The learning model is a variation of teaching carried out by the teacher to improve students' thinking skills, increase student involvement in the learning process so that students feel a meaningful learning, and reduce student saturation in learning [3].
The use of the learning model in this study is a GI learning model combined with TPS and CRH. The first model used is the GI learning model. Group Investigation learning model is a learning model that emphasizes student choice and control rather than applies the teaching techniques in the classroom. In addition, it also combines democratic learning principles where students are seen actively in learning activities both from the beginning to the end of learning [8].

The second learning model that is used and is a support of the first model is the TPS cooperative learning model. The cooperative learning model is used in this learning because the cooperative learning model guides students to collaborate in a small group. The students will be guided to solve a common problem with peers so that in groups students will be taught to help each other in solving problems and being responsible with their groups. One of the cooperative learning models is the TPS learning model. The TPS learning model or thinking in pairs is a type of cooperative learning designed to influence student interaction patterns. Basically, this model is an effective way to vary the atmosphere of class discussion patterns. Assuming that all discussions require arrangements to control the class as a 
whole and the procedures used in this model can give students more time to think to respond and help each other [9].

The third learning model that supports the first and second models is the CRH learning model. CRH is a learning method that can create a festive and pleasant classroom atmosphere because every student who answers correctly is obliged to shout e hooray!!! or other yells they like. Increasing each aspect of teacher activity is inseparable from the important role of a teacher as a planner of the learning program implemented [6].

Student activities that have been carried out in IPS learning Preparatory Material for Indonesian Independence using a GI model combination with TPS and CRH experienced an increasing tendency in each meeting and succeeded in achieving the success indicator namely $\geq 82 \%$ of students achieved active and very active criteria.

The increase in student activity that occurred in this learning was due to the accuracy of the teacher in carrying out learning about Indonesian independence preparation material using the GI model in combination with TPS and CRH. This accuracy helps students to learn the material gradually, leads students to be able to work in a small group and increases the courage of students to express their opinions in front of the others. This is also supported by the activities of students who are involved in the learning process and the high enthusiasm of students in following the learning model. In addition, students have also been able to express their opinions with confidence through guidance from the teacher.

Based on the evaluation test results in cycles 1 to 2 in the implementation of this class action, it can be seen that there is an increase in student learning outcomes gradually in the social studies learning process about preparation for Indonesian independence in the VB class GI learning model in combination with TPS and CRH.

With these results, it is proven that the GI learning model combined with TPS and CRH can improve student learning outcomes. The above description is in accordance with Susanto's opinion that "learning outcomes are abilities acquired by children after going through learning activities", learning activities here are carried out by teachers in the classroom [3].

The low value of classical completeness in cycle 1 is because the students have not been able to compare well about several efforts in preparing for Indonesian independence conducted between BPUPKI and PPKI. Also, it is with the students who are less able to compare the basic formulation of the state given an explanation by the teacher and are less able to cooperate in a group so that a problem cannot be resolved properly. In cycle 2 , there is an increase in student learning completeness where the classical completeness of students reaching $96 \%$. This increase is caused by the teacher who has directed well the parts that have not been understood by students so that at the time of evaluation the students have been able to answer the questions given. The description above is in accordance with Sudjana's opinion which suggests that "learning outcomes are abilities possessed by students after they experience the learning" [10].
Through this discussion, this study is also supported by the results of relevant research using a GI learning model combined with TPS and CRH. This study is also supported by the results of relevant research studies using GI learning model combined with TPS and CRH learning models. The application of the GI model has an effect on conceptual knowledge as well as can increase teacher activity, learning outcomes, and student activities [11][12][13][14].

The application of TPS model in the learning process can improve the understanding of basic concepts, student learning outcomes, and able to increase teacher activity in the learning process [15][16][17]. The application of the Course Review Horay model in the learning can improve student understanding [18].

\section{CONCLUSION}

It can be concluded that on the implementation of the GI model combined with TPS and CRH in studying Indonesian independence preparation material, the teacher activities can be carried out in very good category, the student activities can be improved with very active category, and student learning outcomes increase classically reaching $96 \%$ of the students.

\section{REFERENCES}

[1] S. Sutikno, Belajar dan pembelajaran, Lombok: Holistica, 2013.

[2] R.I. Undang-Undang, No. 20 tahun 2003 tentang Sistem Pendidikan Nasional. Bandung: Citra Umbara, 2003

[3] A. Susanto, Teori belajar dan pembelajaran di sekolah dasar," Jakarta: Kencana Prenada Media Group, 2014.

[4] S. Sapriya, Konsep dasar IPS, Bandung: Laboratorium PKN Universitas Pendidikan Indonesia, 2008.

[5] Z. Zainuddin, F. Fitriani, and M. Misbah, "Development of a senior high school on dynamic fluid learning material in the setting of group investigation type of cooperative learning," In Prosiding Seminar Nasional Fisika (SNF), vol. 1, pp. 109-116, 2017.

[6] M. Huda, Model-model pengajaran dan pembelajaran, Yogyakarta: Pustaka Pelajar, 2015.

[7] D. Anggraeni, "Peningkatan kualitas pembelajaran ips melalui model pembelajaran kooperatif tipe course review horay pada siswa kelas iv sd negeri sekaran 01 semarang (improving social instructional quality by cooperative model, course review horay type at fourth SDN," Jurnal Kreatif: Jurnal Kependidikan Dasar, vol. 1, no. 2, 2011.

[8] A. Shoimin, 68 Model pembelajaran inovatif dalam kurikulum 2013, Yogyakarta: Ar-ruzz Media, 2014.

[9] I. Kurniasih, and Sani B, Ragam Pengembangan Model Pembelajaran, Jakarta: Kata Pena, 2015.

[10] N. Sudjana, Penilaian Hasil Proses Belajar Mengajar, Bandung: Rosdikarya, 2016.

[11] R. Almeda, "Effect of cooperative learning model type group investigation assisted PhET to students' conceptual knowledge," IOSR Journal of Research \& Method in Education (IOSR-JRME), vol. 7, no. 4, 2017.

[12] D. Apriyani, Penerapan Model Group Investigatinon (GI) Untuk Meningkatkan Hasil Belajar Siswa Sekolah Dasar, Lampung: Universitas Bandar Lampung, 2015.

[13] M. A. Saputra, Meningkatkan Hasil Belajar IPS Pada Materi Koperasi Melalui Model Group Investigation (GI) dikombinasikan dengan Number Head Together (NHT) dan Talking Stick pada kelas V SDN Guntung Payung 3 Banjarbaru," Banjarmasin: Universitas Lambung Mangkurat, 2013.

[14] A. N. Maesyaroh, Meningkatkan Aktivitas Siswa PKN Kelas IV Materi Globalisasi Degan Menggunakan Model Group Investigation (GI) 
divariasikan dengan Number Head Together (NHT) dan Word Square SDN Belitung Selatan 9 Banjarmasin," Banjarmasin: Universitas Lambung Mangkurat, 2013.

[15] B. U. P. Aji, Penerapan model think pair and share (TPS) untuk meningkatkan pemahaman konsep uang pada siswa kelas iii sekolah dasar, Surakarta: Universitas Sebelas Maret, 2017.

[16] A. B. Setiawan, Meningkatkan hasil belajar siswa materi membaca denah dengan model pembelajaran integrasi membaca dan komposisi (CIRC) dikombinasikan dengan Think Pair And Share (TPS) di kelas
IV SDN 1 Kemuning Banjarbaru, Banjarmasin: Universitas Lambung Mangkurat, 2016.

[17] D. Triwulandari, M. Wati, and A. Salam, "Perbedaan Hasil Belajar Siswa Antara Menggunakan Model Pembelajaran Kooperatif Tipe Think Pair Share Dengan Tipe Pair Checks Pada SMP Negeri 9 Banjarmasin," Berkala Ilmiah Pendidikan Fisika, vol. 5, no. 1, 2017.

[18] I. U. Z. Arrahmah, and S. Suharno, "Penerapan Model Pembelajaran Course Review Horay (CRH) untuk Meningkatkan Pemahaman Konsep Jasa dan Peranan Tokoh-Tokoh Kemerdekaan pada Siswa Sekolah Dasar," Jurnal Didaktika Dwija Indria (SOLO), vol. 5, no. 2, 2017. 